\title{
Quantification of growth factors in allogenic bone grafts extracted with three different methods
}

\author{
B. Wildemann · A. Kadow-Romacker • \\ A. Pruss $\cdot$ N. P. Haas $\cdot$ G. Schmidmaier
}

Received: 14 March 2006/ Accepted: 22 May 2006/Published online: 25 October 2006

(C) Springer Science+Business Media B.V. 2006

\begin{abstract}
Background Bony allografts are used for defect filling. A reliable sterilization method is the peracetic acid-ethanol sterilization procedure (PES). Several studies showed the antimicrobiological efficacy of this method. Aim of this study was the quantification of growth factors necessary for bone formation in PES sterilized allografts $(n=9)$.

Methods To extract the growth factors from the tissue three different methods were used: (a) use of collagenase 1 for extraction, (b) incubation of the material in a proteinase inhibitor cocktail (Complete), and (c) extraction with guanidine $\mathrm{HCl}$. The supernatants from the different methods were analyzed for the total protein concentration and different growth factors.

Results The extraction with guanidine $\mathrm{HCl}$ resulted in the highest amount of protein measurable
\end{abstract}

B. Wildemann $(\bowtie) \cdot$ A. Kadow-Romacker .

N. P. Haas · G. Schmidmaier

Center for Musculoskeletal Surgery, Charité-

Universitätsmedizin Berlin, Augustenburger Platz 1,

D-13353 Berlin, Germany

e-mail: Britt.Wildemann@charite.de

A. Pruss

Institute for Transfusion Medicine (Tissue Bank), Charité-Universitätsmedizin Berlin, Berlin, Germany in the supernatants of the samples. For comparison of the individual growth factor values the results were normalized to the protein content. The highest growth factor amount/protein was detectable for BMP-2 using the GndHCL method followed by FGFa, IGF-I, TGF- $\beta 1$, VEGF, and PDGF. Comparing the three extraction methods, significant differences were measured for the individual growth factor content.

Conclusion PES sterilized bony allografts contain several growth factors. Depending on the extraction method, the quantity of the analyzed growth factors varies.

Keywords Allograft - Growth factors ·

Extraction method $\cdot$ Collagenase $\cdot$ Guanidine

$\mathrm{HCl} \cdot$ Proteinase inhibitor $\cdot$ Peracetic

acid-ethanol sterilization (PES)

$\begin{array}{ll}\text { Abbreviations } \\ \text { BMP } & \text { Bone morphogenetic growth factor } \\ \text { DBM } & \text { Demineralized bone matrix } \\ \text { ELISA } & \text { Enzyme linked immunosorbant assay } \\ \text { FGF } & \text { Fibroblast growth factor } \\ \text { GndHCL } & \text { Guanidine HCl } \\ \text { IGF-I } & \text { Insulin like growth factor-I } \\ \text { PBS } & \text { Phosphate buffered saline } \\ \text { PES } & \text { Peracetic acid-ethanol sterilization } \\ \text { PDGF } & \text { Platelet derived growth factor } \\ \text { TGF- } \beta 1 & \text { Transforming growth factor-beta1 } \\ \text { VEGF } & \text { Vascular endothelial growth factor }\end{array}$




\section{Introduction}

Bone defects are a major problem in orthopaedic surgery. The gold standard for defect filling is the use of autogenic bony material. Due to complications associated with the harvesting of autogenic material (Sasso et al. 2005; Silber et al. 2003; Skaggs et al. 2000), allogenic or alloplastic materials might be an alternative grafting material. In the ideal case, this material is biocompatible, not infective, resorbable, osteoconductive, and osteoinductive. Osteoconduction means that bone growth onto a surface or into a given three-dimensional structure (Albrektsson and Johansson 2001). Osteoinduction is a necessary process for bone formation because it describes the recruitment of undifferentiated pluripotent cells and their stimulation to differentiate into bone forming cells (Albrektsson and Johansson 2001). Allogenic grafts fulfil the demand of osteoconductivity. These grafts can either be cancellous or cortical in nature. Both variants allow the revascularization and the migration of bone forming and resorbing cells onto and into the tissue (Ripamonti et al. 1993; Stiehl 2004; Taira et al. 2004). Therefore, the graft serves as a structure for new bone formation. Osteoinduction is a further necessary process for optimal graft ingrowth. Growth factors such as IGF-I, TGF- $\beta 1$, VEGF, etc, are osteoinductive and promote bone formation (Bolander 1992; Lane et al. 1999; Lind and Bunger 2001; Schliephake 2002). The tissue processing of the grafts such as sterilization, however, might influence the growth factors.

Methods for inactivation of bacteria and viruses use ethylene oxide (EtO), gamma irradiation (Bright 1987) or thermal treatment with moist heat (Hofmann et al. 1996; Knaepler et al. 1994). A possible reduction of the osteoinductive potential by ethylene oxide sterilization is under controversial discussion (Aspenberg and Lindqvist 1998; Thoren and Aspenberg 1995; Zhang et al. 1997). Starting in 1967 EtO was replaced by the use of beta-propiolactone (Geesink 2002) and gamma radiation of $25 \mathrm{kGy}$ (International Atomic Energy Agency (IAEA) 1990). Gamma irradiation, however, might promote the formation of toxic radicals and have a negative effect on biochemical parameters (Moreau et al. 2000; Rock 1991). Since beta-propiolactone sterilization also showed, to an increasing extent, problems such as toxicity, a new process on a low-pressure basis, i.e., peracetic acid-ethanol sterilization (PES) (Sprossig and Mucke 1968; Wutzler and Sauerbrei 2000), was introduced (von Versen et al. 1992). The PES treatment for allogenic avital bony tissue is a reliable sterilization method (Pruss et al. 2003). Several studies validated the efficacy of this method on selected viruses, bacteria, fungi, and spores and compared this method with other sterilization method (Pruss et al. 2001; Pruss et al. 2003).

Haynert, Thielecke et al., and Kuhls et al. studied in the framework of clinical feasibility studies the osteoinductive capabilities or integrating ratios of PES sterilized dematerialized bone matrix (DBM) (Haynert 1990; Kuhls et al. 2001; Thielicke et al. 1990). It was reported unanimously that the PES does not cause any significant reductions of the osteoinductive effects and that the transplanted DBM shows excellent integrating results. A retrospective report of clinical experience of the years 1997-2001 on the overall scope of tissue grafts (total of 16,823 transplants) showed a good up to very good clinical efficacy without clinically relevant side effects (Pruss et al. 2002). Goal of the present study was to quantify growth factors necessary for bone formation in PES sterilized allograft material using different extraction methods.

\section{Materials and methods}

\section{Samples}

Allografts $(n=9)$ were provided by the tissue bank of the Charité. Potential bone tissue donors were clinically examined for a variety of infectious diseases. The approved material was processed with the PES procedure (PES) for allogenic avital bone transplants as described previously (Pruss et al. 2001). Briefly, the chloroform-methanol defatted bony material was incubated at low pressure (200 mbar) at room temperature for $4 \mathrm{~h}$ under agitation in $2 \%$ peracetic acid, $96 \%$ ethanol, Aqua (2:1:1). 
Demographic data of the donors: 5 male, age: $43 \pm 19.4$ (18-67 years); 4 female, age: $52.3 \pm 10.6$ (40-66 years). From all donors the femora were used.

\section{Sample preparation}

The sterile allografts were pulverized using a cooled mill (Retsch, Germany). The homogenized bony material was diluted in accordance to one the following procedures.

(a) Collagenase Extraction: One gram sample was placed in $15 \mathrm{ml}$ centrifuge tubes, and covered with $3 \mathrm{ml}$ of $20 \mathrm{mM}$ Tris buffer plus $20 \mathrm{U} / \mathrm{ml}$ Collagenase Type 1 . After incubation at $37^{\circ} \mathrm{C}$ in a shaking water bath over night the tubes were centrifuged for $20 \mathrm{~min}$ at $12,000 \mathrm{rpm}$. After centrifugation, the supernatant was dialyzed against aqua dest over night at $4^{\circ} \mathrm{C}$ with three changes and thereafter stored at $-80^{\circ} \mathrm{C}$ (modified after (Blum et al. 2004; Laitinen et al. 1997)).

(b) Proteinase Inhibitor (Complete): Two gram sample was incubated for $2 \mathrm{~h}$ with $5 \mathrm{ml}$ Proteinase inhibitor (Complete, Roche, Mannheim, Germany) at $4^{\circ} \mathrm{C}$. After extraction the samples were centrifuged by $12,000 \mathrm{rpm}$ for $10 \mathrm{~min}$ and the supernatant was stored at $-80^{\circ} \mathrm{C}$.

(c) Guanidine $\mathrm{HCl} / \mathrm{EDTA}$ method: Thirty milligram of sample were placed in $1.5 \mathrm{ml}$ Eppendorf tubes with $1.9 \mathrm{ml} 4 \mathrm{M}$ Guanidine $\mathrm{HCl}, 50 \mathrm{mM}$ EDTA in $50 \mathrm{ml}$ Tris $\mathrm{pH} 7.4$ plus $5 \mathrm{mM}$ benzamidine- $\mathrm{HCl}, 1 \mathrm{mM}$ phenylmethylsulfonyl, and $0.1 \mathrm{mM}$ aminocaproic acid. The samples were dialyzed against aqua dest at $4^{\circ} \mathrm{C}$ for $24 \mathrm{~h}$ with four changes (modified after (Pepene et al. 2004; Sampath and Reddi 1981)).

After extraction the samples were centrifuged by $12,000 \mathrm{rpm}$ and the supernatant was stored at $-80^{\circ} \mathrm{C}$.
Protein and growth factor quantification

To quantify the total protein concentration a Coomassie Plus Protein Assay (Pierce, Perbio Science GmbH, Germany) was used. IGF-I, TGF$\beta 1$, BMP-2, BMP-4, PDGFbb, FGFa, FGFb, and VEGF concentration in the extracts were quantified using ELISA-methods (all kits were obtained from R\&D-Systems, Wiesbaden, Germany). The analyses were performed according to the instructions of the manufacturer. Briefly, samples and standards were added to growth factor antibody coated 96 well plates. After incubation and removal of the unbound substances an enzyme coupled secondary antibody was added. This step was followed by a further washing step and incubated with a substrate. The color reaction was stopped and the optical density measured at the appropriate wavelength. If necessary, samples were pretreated as mentioned in the manufactures instructions.

Statistical analysis

The values are reported as mean $\pm \mathrm{SD}$. In the case that no growth factor value was determined with the ELISA, the sample was excluded from further statistical evaluation (see Table 1). Comparison of data was performed using ANOVA for global comparison and controlled with Bonferroni correction for multiple testing. Statistical differences were defined at a $95 \%$ confidence level. SPSS (release 12.0; SPSS Inc. Chicago, Illinois) software supported statistical evaluation.

\section{Results}

From eight analyzed growth factors were seven detectable in the allografts (FGFb was not detectable). From the detectable seven growth factors not all the factors were measurable in
Table 1 Number of allografts in which the growth factors were detectable

\begin{tabular}{lllllllll}
\hline & Protein & BMP-2 & IGF-I & VEGF & FGFa & TGF- $\beta 1$ & PDGF & BMP-4 \\
\hline Collagenase & 9 & 2 & 8 & 4 & 6 & 3 & 7 & 0 \\
Complete & 9 & 2 & 9 & 6 & 8 & 1 & 6 & 7 \\
GndHCl & 9 & 9 & 9 & 5 & 8 & 2 & 8 & 0 \\
\hline
\end{tabular}


every allograft (Table 1). A relation of these differences in respect to donor age or gender was not accessible.

\section{Total protein}

The nine allografts were homogenized in the same way. The proteins were extracted using three different methods: extraction with Collagenase digestion, incubation in PBS with proteinase inhibitor (Complete), or with the guanidine $\mathrm{HCl}$ method. Significantly more protein per $\mathrm{g}$ tissue was extracted using the guanidine $\mathrm{HCl}$ method (Fig. 1). Almost $10 \mathrm{mg}$ protein was extracted from $1 \mathrm{~g}$ sample with this method. This is 24 times more compared to the Complete and 39 times more compared to the Collagenase method. Due to the differences in the extraction efficacy, the following growth factor data were normalized to the protein content of the samples.

\section{Quantification of growth factors}

The growth factor BMP-4 was only detectable after the extraction with the Complete method. In seven of nine samples BMP-4 was measurable with an average value of $0.17 \mathrm{pg} / \mu \mathrm{g}$ protein and a $\mathrm{SD}$ of $0.06 \mathrm{pg} / \mu \mathrm{g}$ (see Table 2, per g allograft).

The highest growth factor value compared to total protein was detectable for BMP-2. After $\mathrm{GndHCl}$ extraction $450 \pm 273$ pg BMP-2 per $\mu \mathrm{g}$ protein were measured (Fig. 2). This value was dramatically higher compared to the value assessed after Collagenase $(1.5 \pm 0.7 \mathrm{pg} / \mu \mathrm{g})$ or Complete extraction $(1.9 \pm 1.07 \mathrm{pg} / \mu \mathrm{g})$. Using the $\mathrm{GndHCl}$ method in all nine allografts BMP-2 was detectable whereas in both other methods only in

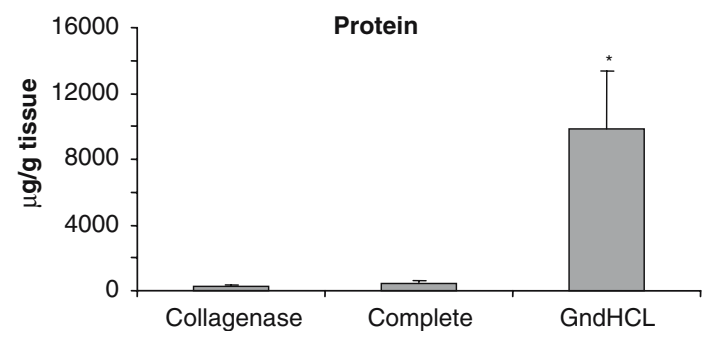

Fig. 1 Protein content per gram sample. Significantly more protein was extracted from the samples after $\mathrm{GndHCl}$ extraction compared to both other methods, $* P<0.001$

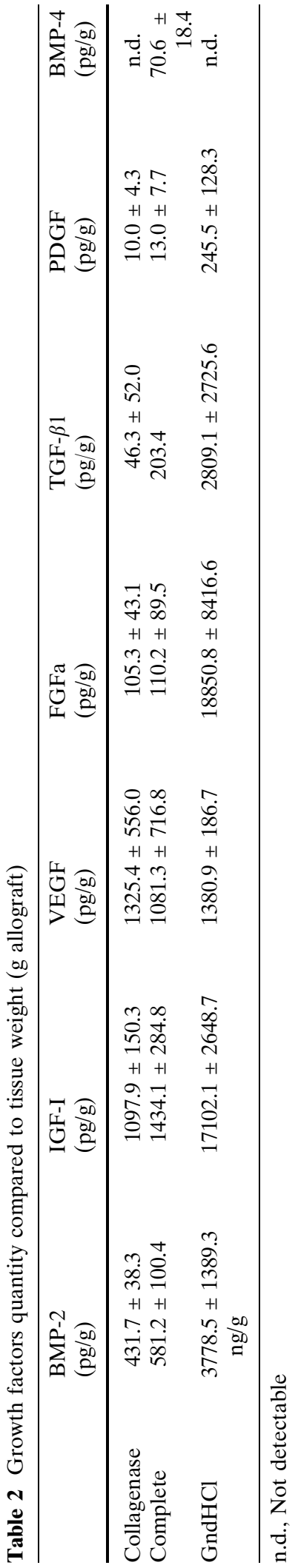




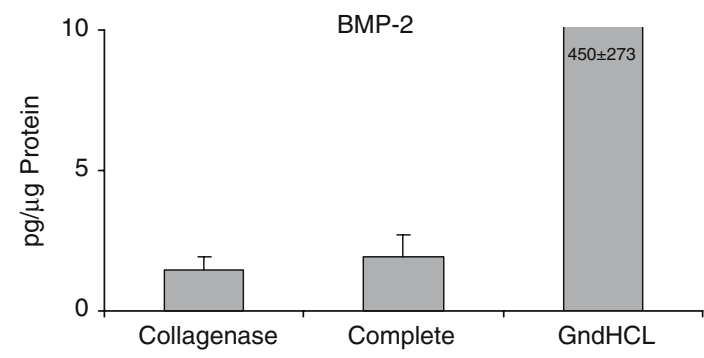

Fig. 2 Quantification of BMP-2 [pg/ $\mu$ g Protein] in allografts using three different extraction methods. The BMP2 content is correlated to the total protein content of the samples. Using the Collagenase or the Complete Method in only two of nine samples was BMP-2 detectable

two allografts, therefore, the difference was not significant. The level of IGF-I and VEGF were significantly higher after Collagenase extraction compared to the GndHCl method (Figs. 3, 4). In contrast, FGFa revealed a significantly higher value after $\mathrm{GndHCl}$ extraction compared to both other methods (Fig. 5). No significant differences were measurable for the growth factors TGF- $\beta 1$ and PDGF (Figs. 6, 7). TGF- $\beta 1$ was detectable only in one to three of nine samples with the three

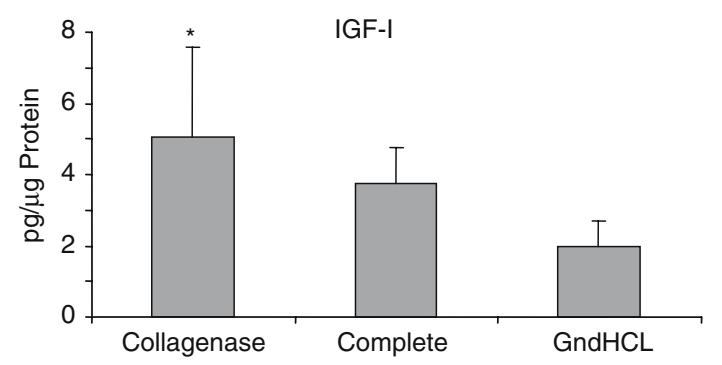

Fig. 3 Quantification of IGF-I [pg/ $\mu$ g Protein] in allografts using three different extraction methods, $* P=0.003$ compared to $\mathrm{GndHCl}$

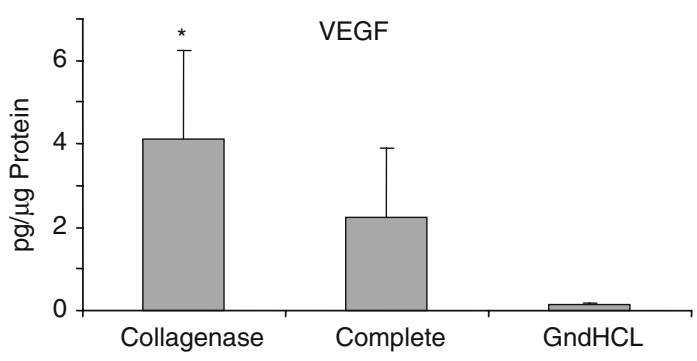

Fig. 4 Quantification of VEGF [pg/ $/ \mathrm{g}$ Protein] in allografts using three different extraction methods, $* P=0.014$ compared to $\mathrm{Gnd} \mathrm{HCl}$

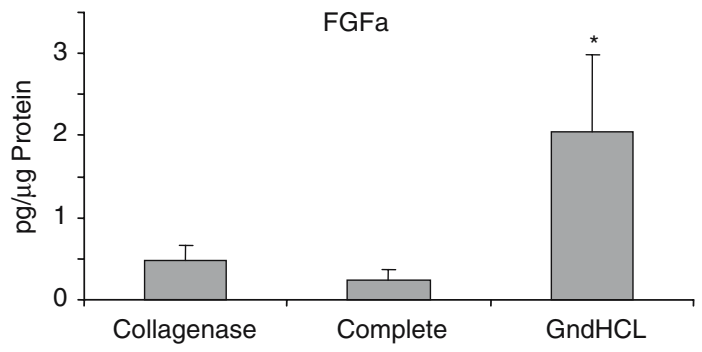

Fig. 5 Quantification of FGFa [pg/ $\mu$ g Protein] in allografts using three different extraction methods, $* P<0.001$ compared to both methods

different methods. Not all method extracted TGF- $\beta 1$ from the same samples (Table 1 ).

\section{Discussion}

One important question using allografts for bone defect filling is the content of growth factors in the graft material. Therefore, aim of this study was the quantification of growth factors in PES sterilized allografts.

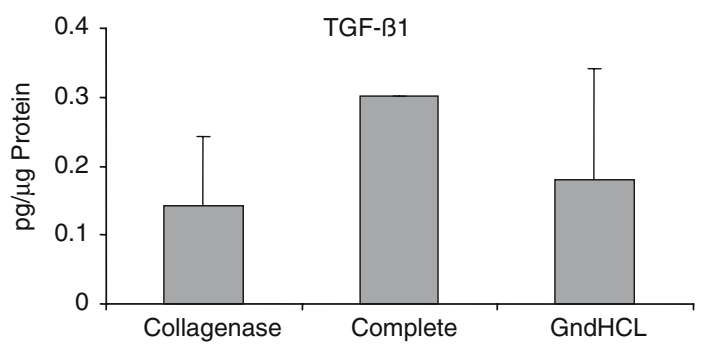

Fig. 6 Quantification of TGF- $\beta 1$ [pg/ $\mu$ g Protein] in allografts using three different extraction methods

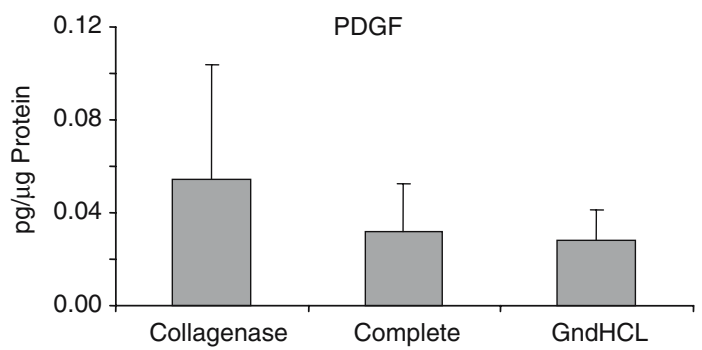

Fig. 7 Quantification of PDGF $[\mathrm{pg} / \mu \mathrm{g}$ Protein] in allografts using three different extraction methods 
From the eight investigated growth factors seven were detectable in the allografts: BMP-2, BMP-4, IGF-I, VEGF, FGFa, TGF- $\beta 1$, and PDGF. FGFb was not detectable in any sample.

Three different methods for protein extraction were used which also differ in the handling and the preparation time. The elution of the homogenized bony material in PBS plus proteinase inhibitor (Complete) is very easy and fast. The two other methods - collagenase digestion (Blum et al. 2004; Laitinen et al. 1997) and guanidine $\mathrm{HCl}$ extraction (Pepene et al. 2004; Sampath and Reddi 1981) — are time consuming and laborious. Significant differences were found in the amount of extracted total protein. The highest value was obtained with the guanidine $\mathrm{HCl}$ method (app. $10 \mathrm{mg} / \mathrm{g}$ sample). With the two other methods significant but comparable lower values were measured. Differences were also detectable in the amount of the measured growth factors. To overcome the differences in the extraction efficacy, we normalized the growth factor content to the total protein value obtained by each method. BMP-4, however, was only detectable after PBS and proteinase inhibitor extraction (Complete method). A nearly comparable succession of growth factors was obtained with the three methods but significant differences were measurable in the value of the individual growth factors depending on the extraction method. The highest BMP-2 value was obtained after $\mathrm{GndHCl}$ extraction. The $\mathrm{GndHCl}$ extraction showed also for FGFa the highest extraction value compared to both other methods. Using the Collagenase digestion, IGF-I and VEGF were extractable in a significantly higher value compared to the $\mathrm{GndHCl}$ method. These results clearly demonstrate the importance of the extraction method. A comparison of growth factor values is only possible, when the same extraction protocols were used.

The study shows that using the guanidine extraction method significantly more protein can be extracted. This method however is time consuming and needs much more different chemicals. For a comparison of growth factors or different materials we can recommend the easy and fast proteinase method. This is the first study that quantified growth factors in allografts. The limitations of the study are that it is hardly possible to make a conclusion, if these detected amounts are sufficient to induce new bone formation and that the bioactivity was not tested. The quantification with ELISA method gives no information concerning the bioactivity of the growth factors. A 2005 published study by Honsawek, however, showed a good correlation between the osteoinductivity of demineralized bone matrix (DBM) and the BMP-4 content measured by ELISA method (Honsawek et al. 2005). DBMs with high BMP-4 level demonstrated the highest osteoinductivity in the mouse bioassay. In addition, several studies were able to demonstrate an osteoinductive potential of allografts (Kubler et al. 1995; Lohmann et al. 2001; Pinholt and Solheim 1998). Hansen et al. used PES-sterilized demineralized bone matrix for filling of critical size craniotomy defects. Compared to the unfilled defects, they describe bone defect bridging by newly formed woven bone with incorporated DBM residues on day 84 (Hansen et al. 2001). These results, taken together with the quantification of growth factors in human allografts, support the hypothesis that allografts have an osteoinductive potential and promote the graft incorporation. However, further in vivo and in vitro investigation on the bioactivity of the detected growths factors in the allograft should be performed.

Acknowledgment The authors gratefully thank Sven Schurig for tissue harvesting and preparation. This study was supported by a research grant from the Charité.

\section{References}

Albrektsson T, Johansson C (2001) Osteoinduction, osteoconduction and osseointegration. Eur Spine J 10(Suppl 2):S96-101

Aspenberg P, Lindqvist SB (1998) Ethene oxide and bone induction. Controversy remains. Acta Orthop Scand 69:173-176

Blum B, Moseley J, Miller L, Richelsoph K, Haggard W (2004) Measurement of bone morphogenetic proteins and other growth factors in demineralized bone matrix. Orthopedics 27: s161-s165

Bolander ME (1992) Regulation of fracture repair by growth factors. Proc Soc Exp Biol Med 200:165-170

Bright RW (1987) Sterilization of human bone by irradiation. In: Friedlaender G (ed) Osteochondral allografts, biology, banking and clinical application. Little Brown, Boston, Toronto, pp 223-232 
Geesink RG (2002) Osteoconductive coatings for total joint arthroplasty. Clin Orthop Relat Res Feb(395):53-65

Hansen A, Pruss A, Gollnick K, Bochentin B, Denner K, Von Versen R (2001) Demineralized bone matrix-stimulated bone regeneration in rats enhanced by an angiogenic dipeptide derivate. Cell Tissue Bank 2:69-75

Haynert W (1990) Application possibilities of human bone-collagen substance as a transplant in skeletal surgery. Beitr Orthop Traumatol 37:453-461

Hofmann C, von Garrel T, Gotzen L (1996) Bone bank management using a thermal disinfection system (Lobator SD-1). A critical analysis. Unfallchirurg 99:498-508

Honsawek S, Powers RM, Wolfinbarger L (2005) Extractable bone morphogenetic protein and correlation with induced new bone formation in an in vivo assay in the athymic mouse model. Cell Tissue Bank 6:13-23

International Atomic Energy Agency (IAEA) (1990) Guidelines for industrial radiation sterilization of disposable medical products (Cobalt-60 Gamma Irradiation). IAEA-TECDOC-539 Vienna: IAEA 39

Knaepler H, von Garrel T, Gotzen L (1994) Untersuchungen zur Desinfektion und Sterilisation allogener Knochentransplantate. Hefte z d Unfallchirug 235:1-101

Kubler N, Michel C, Zoller J, Bill J, Muhling J, Reuther J (1995) Repair of human skull defects using osteoinductive bone alloimplants. J Craniomaxillofac Surg 23:337-346

Kuhls R, Werner-Rustner M, Kuchler I, Soost F (2001) Human demineralised bone matrix as a bone substitute for reconstruction of cystic defects of the lower jaw. Cell Tissue Bank 2:143-153

Laitinen M, Jortikka L, Halttunen T, Nevalainen J, Aho AJ, Marttinen A, Lindholm TS (1997) Measurement of total and local bone morphogenetic protein concentration in bone tumours. Int Orthop 21:188-193

Lane JM, Tomin E, Bostrom MP (1999) Biosynthetic bone grafting. Clin Orthop Relat Res Oct(367 Suppl):S107S117

Lind M, Bunger C (2001) Factors stimulating bone formation. Eur Spine J 10(Suppl 2):S102-S109

Lohmann CH, Andreacchio D, Koster G, Carnes DL Jr., Cochran DL, Dean DD, Boyan BD, Schwartz Z (2001) Tissue response and osteoinduction of human bone grafts in vivo. Arch Orthop Trauma Surg 121:583-590

Moreau MF, Gallois Y, Basle MF, Chappard D (2000) Gamma irradiation of human bone allografts alters medullary lipids and releases toxic compounds for osteoblast-like cells. Biomaterials 21:369-376

Pepene CE, Seck T, Diel I, Minne HW, Ziegler R, Pfeilschifter J (2004) Concentration of insulin-like growth factor (IGF)-I in iliac crest bone matrix in premenopausal women with idiopathic osteoporosis. Exp Clin Endocrinol Diabetes 112:38-43

Pinholt EM, Solheim E (1998) Osteoinductive potential of demineralized rat bone increases with increasing donor age from birth to adulthood. J Craniofac Surg 9:142-146

Pruss A, Gobel UB, Pauli G, Kao M, Seibold M, Monig HJ, Hansen A, Von Versen R (2003) Peracetic acidethanol treatment of allogeneic avital bone tissue transplants - a reliable sterilization method. Ann Transplant 8:34-42

Pruss A, Hansen A, Kao M, Gurtler L, Pauli G, Benedix F, Von Versen R (2001) Comparison of the efficacy of virus inactivation methods in allogeneic avital bone tissue transplants. Cell Tissue Bank 2:201-215

Pruss A, Perka C, Degenhardt P, Maronna U, ButtnerJanz K, Paul B, Muller K, Klumpp C, Bruck JC, Von Versen R (2002) Clinical efficacy and compatibility of allogeneic avital tissue transplants sterilized with a peracetic acid/ethanol mixture. Cell Tissue Bank 3:235-243

Ripamonti U, Petit JC, Moehl T, van den HB, van Wyk J (1993) Immediate reconstruction of massive cranioorbito-facial defects with allogeneic and alloplastic matrices in baboons. J Craniomaxillofac Surg 21:302-308

Rock MG (1991) Biomechanics of allografts. In: Czitrom AA, Winkler H (eds) Orthopedic allograft survey. Springer, Wien, New York, pp 29-37

Sampath TK, Reddi AH (1981) Dissociative extraction and reconstitution of extracellular matrix components involved in local bone differentiation. Proc Natl Acad Sci USA 78:7599-7603

Sasso RC, Lehuec JC, Shaffrey C (2005) Iliac crest bone graft donor site pain after anterior lumbar interbody fusion: a prospective patient satisfaction outcome assessment. J Spinal Disord Tech 18:S77-S81

Schliephake H (2002) Bone growth factors in maxillofacial skeletal reconstruction. Int J Oral Maxillofacial Surg 31:469-484

Silber JS, Anderson DG, Daffner SD, Brislin BT, Leland JM, Hilibrand AS, Vaccaro AR, Albert TJ (2003) Donor site morbidity after anterior iliac crest bone harvest for single-level anterior cervical discectomy and fusion. Spine 28:134-139

Skaggs DL, Samuelson MA, Hale JM, Kay RM, Tolo VT (2000) Complications of posterior iliac crest bone grafting in spine surgery in children. Spine 25:24002402

Sprossig M, Mucke H (1968) On the antimicrobial effect of peracetic acid. 5. Studies on the virucidal effect. Pharmazie 23:665-667

Stiehl JB (2004) Revascularization of a total bulk acetabular allograft at 14 years. J Arthroplasty 19:508-512

Taira H, Moreno J, Ripalda P, Forriol F (2004) Radiological and histological analysis of cortical allografts: an experimental study in sheep femora. Arch Orthop Trauma Surg 124:320-325

Thielicke U, Thielicke B, Von Versen R, Denner K (1990) Clinical study on the application of demineralized bone matrix (DBM) in surgical orthodontics. Beitr Orthop Traumatol 37:461-465

Thoren K, Aspenberg P (1995) Ethylene oxide sterilization impairs allograft incorporation in a conduction chamber. Clin Orthop Relat Res Sep(318):259-264 
von Versen R, Heider H, Kleemann I, Starke R (1992) Chemische Sterilisation biologischer Implantate mit einer Kombinationsmethode. Osteologie aktuell VII:380-386

Wutzler P, Sauerbrei A (2000) Virucidal efficacy of a combination of $0.2 \%$ peracetic acid and $80 \%(\mathrm{v} / \mathrm{v})$ ethanol (PAA-ethanol) as a potential hand disinfectant. J Hosp Infect 46:304-308

Zhang Q, Cornu O, Delloye C (1997) Ethylene oxide does not extinguish the osteoinductive capacity of demineralized bone. A reappraisal in rats. Acta Orthop Scand 68:104-108 